\title{
NARRATIVAS DE LICENCIANDOS EM FÍSICA SOBRE AS DISCIPLINAS PEDAGÓGICAS
}

HERIÉDNA CARDOSO GUIMARÃES

Universidade Federal Fluminense

EDA MARIA DE OLIVEIRA HENRIQUES

Universidade Federal Fluminense

RESUMO Este texto busca compreender, a partir das narrativas dos licenciandos em fisica de uma universidade federal do Estado do Rio de Janeiro, quais os sentidos que estes atribuem às suas experiências com as disciplinas pedagógicas cursadas no processo de formação inicial. As narrativas das histórias de vida e formação dos licenciandos foram construídas via a realização de entrevistas narrativas, organizadas e textualizadas enquanto Mônadas, que, na perspectiva de Walter Benjamin, constituem pequenas historietas emblemáticas de sentido sobre a centralidade das disciplinas pedagógicas no processo de formação. As lentes utilizadas para a leitura das Mônadas, e os sentidos que produzem sobre a dimensão pedagógica da formação inicial, perpassam contribuições de Walter Benjamin com os conceitos de experiência e narrativa, a discussão sobre as aprendizagens implícitas, proposta por Philip Jackson, entre outros. Os desdobramentos e cruzamentos entre as lentes e as leituras das Mônadas sinalizam, a partir do olhar dos licenciandos, um processo de formação de professores de fisica que, via as disciplinas pedagógicas, conecta a docência em física a discussões e questões da área de humanas, uma vez que esse processo demanda interações intra e intersubjetivas afastando a prática docente do olhar pautado no senso comum.

Palavras-chave: Formação de professores de Física. Disciplinas pedagógicas. Narrativa.

\section{ABSTRACT NARRATIVES OF GRADUATES IN PHYSICS ABOUT PEDAGOGICAL DISCIPLINES}

This text tries to understand, from the narratives of the graduate in physics of a federal university of the state of Rio de Janeiro, what the meanings they attribute to their experiences with the pedagogical disciplines studied in the teachers initial education process. The narratives of life histories and formation of the graduates were constructed 
through narrative interviews, organized and textualized as Monads, which in the perspective of Walter Benjamin, are small text emblematic of meaning about the centrality of the pedagogical disciplines in the process of formation. The lenses used for the reading of the Monads, and the meanings they produce on the pedagogical dimension of initial formation, include Walter Benjamin's contributions to the concepts of experience and narrative, the discussion on implicit learning proposed by Philip Jackson, among others. The unfoldings and crossings between the lenses and the readings of the Monads signal, from the view of the graduation student, a teacher education of the physics that, via the pedagogical disciplines, connects the teaching physics to the discussions and questions of the science of education since this process demands intra and inter subjective interactions going away from the teaching practice based on common sense.

Keywords: Teacher education of the Physics. Pedagogical disciplines. Narrative.

\section{NARRATIVAS DE LOS LICENCIADOS EM FÍSICA SOBRE LAS DISCIPLINAS PEDAGÓGICAS}

Este texto demanda la comprensión, a partir de las narrativas de los licenciados en Física de una federal universitaria del estado de Río de Janeiro, de significados que ellos atribuyen a sus experiencias con las disciplinas pedagógicas cursadas em su proceso de formación inicial. Las narrativas de las historias de vida y formación de los licenciandos fueron construidas vía la realización de entrevistas narrativas, organizadas y texturadas como Mónadas, que en la perspectiva de Walter Benjamin constituyen pequeñas historietas emblemáticas de sentido sobre la centralidad de las disciplinas pedagógicas en el proceso de formación. Las lentes utilizadas para la lectura de las Mónadas, y los sentidos que producen sobre la dimensión pedagógica de la formación inicial, pasan a las contribuciones de Walter Benjamin con los conceptos de experiencia y narrativa, la discusión sobre los aprendizajes implícitos propuesta por Philip Jackson, entre otros. Los desdoblamientos y intersecções entre las lentes y las lecturas de las Mónadas señalan, a partir de la mirada de los licenciandos, un proceso de formación de profesores de física que, vía las disciplinas pedagógicas, conecta la docencia en física a discusiones y cuestiones del área de humanas puesto que ese proceso demanda interacciones intra e inter subjetivas alejando la práctica docente de la mirada pautada en el sentido común.

Palabras clave: Formación de profesores de Física. Disciplinas pedagógicas. Narrativa 


\section{Os caminhos de formação como}

\section{processos}

Pensar a formação de professores como um processo é admitir "a copresença do passado, presente e futuro" (JOSSO, 2010, p. 62), nos diferentes aspectos englobados pelos/e nos processos de formação. É considerando a interconexão dos diferentes tempos, a dinâmica experienciada pelos sujeitos na construção de suas experiências de formação que procuramos compreender, a partir da escuta das narrativas dos licenciandos em física de uma universidade federal do Estado do Rio de Janeiro, quais os sentidos que estes atribuem às suas experiências com as disciplinas pedagógicas, ao longo do seu processo inicial de formação. Outro aspecto importante e norteador deste texto é a perspectiva híbrida, no que se refere ao modo de olhar os processos de construção do conhecimento, que encontra eco nas investigações (auto)biográficas e na proposição de Antonio Bolívar (2014), como a realização de "una interpretación hermenêutica, donde cada parte adquiere su significado en función del todo, y el informe como totalidade depende - a su vez - del significado de cada parte"1 (BOLÍVAR, 2014, p. 120).

Em relação a aspectos históricos pertinentes à formação inicial de professores de física para atuar no Ensino Médio brasileiro, só há traços a partir do governo de Getúlio Vargas, por meio do Decreto $n^{\circ} 1.190 / 1939$ que passa a legislar sobre cursos de formação de candidatos "ao magistério do ensino secundário em física, matemática, química, história natural" (ARAUJO; VIANNA, 2010, p. 03). Este decreto institui o modelo de formação caracterizado como esquema $3+1$. Após esse início, a licenciatura em física, já secundarizada em relação

1 "uma interpretação hermenêutica, na qual, cada parte adquire seu significado em função do todo, e a história como um todo depende, por sua vez, do significado das partes". ao bacharelado, passou por mudanças externas e impostas, sempre atreladas a interesses políticos passageiros ou de aperfeiçoamento, como: a Resolução S/N, de 17 novembro 1962, publicada pelo Conselho Federal de Educação, que fixou os mínimos de conteúdo para a licenciatura em física; a Lei $n^{\circ} 5.540 / 68$ com a criação dos departamentos; a promulgação da Lei no 5.692/71 com a implementação das licenciaturas de curta duração; as Resoluções 30/71 e 37/75 do Conselho Federal de Educação que transformava, obrigatoriamente, as Licenciaturas em Física, Química, Biologia e Matemática em Licenciatura em Ciências, e definiam um currículo mínimo para o respectivo curso, introduzindo "a figura de professor polivalente" (ARAUJO; VIANNA, 2010, p. 05), sendo as últimas realizadas no contexto político do Regime Militar.

É importante lembrarmos, a partir das contribuições de Deise Vianna, Isa Costa e Lucia Almeida (1988), que nos anos de 1988, momento político de redemocratização brasileira após os 21 anos de Ditadura Militar (1964-1985), haviam 31 instituições (16 federais, 5 estaduais, 2 municipais e 9 particulares) que ofereciam os cursos de licenciatura plena em física e 28 instituições ( 5 federais, 3 estaduais, 1 municipal e 18 particulares) que ofereciam a licenciatura em Ciências com habilitação em física, totalizando 59 instituições que formavam professores de física para atuar na Educação Básica quantitativo muito aquém do necessário para um país com amplo território geográfico como o nosso e que caminhava em direção a uma educação como um direito de todos.

É possível perceber que a licenciatura em física sofreu mudanças significativas, nos últimos 30 anos, como: mudanças na estrutura dos cursos com a implementação dos modelos de 
formação " $3+1$ ", o modelo "2+2", que são modelos marcados pela hierarquia entre os conhecimentos específicos e os pedagógicos, "e a prática assume caráter secundário, fragmentando o conhecimento necessário à docência" (NARDI; CORTELA, 2015, p. 16). Estes aspectos podem ser vistos como herança da perspectiva positivista de ciência que traz no seu bojo a racionalidade técnica e tem como fundamento um conhecimento científico produzido na Europa, durante o século XIX e início do XX, que pretendia não só ditar um modelo de ciência, mas também instituir valores e princípios culturais, sociais e atualmente educacionais.

No contexto da redemocratização e com a nova Constituição, a educação ganhou destaque no cenário nacional como um direito de todos, que, para ser alcançado - ainda que minimamente - tornou necessária a abertura a outros setores sociais, à perspectiva de administração gerencial, participação público-privada, às influências da Declaração de Bolonha, que somadas, corroboram o discurso educacional brasileiro do alcance de metas, do ranqueamento das escolas via os resultados de avaliações externas, como o Exame Nacional do Ensino Médio (ENEM), as políticas de governos implementadas e justificadas a partir dos resultados destas avaliações. Neste contexto está também a Medida Provisória N 746, de 22 de setembro de 2016 (BRASIL, 2016), com os itinerários formativos e o professor polivalente, de modo que, de direito de todos, a educação passou a ser observada como um bem de consumo, um mercado.

Em relação à formação de professores no contexto brasileiro, em especial a partir dos anos de 1980, devido à publicação de diferentes trabalhos (NÓVOA, 1992; 1999; 2010; 2011; GOODSON, 1992; MOITA, 1992; FONTOURA, 1992), têm-se adensado as discussões em torno da indissociabilidade entre o sujeito professor e o profissional professor. Neste sentido, os au- tores consideram que "as opções que cada um de nós tem de fazer como professor, as quais cruzam nossa maneira de ser com a nossa maneira de ensinar e desvendam na nossa maneira de ensinar a nossa maneira de ser" (NÓVOA, 1992, p. 17) são espaços-tempos de diálogo permanente entre o eu sujeito e o eu profissional, e a abertura necessária para a reflexão acerca dos nossos processos de formação.

No âmbito dessas discussões, há a interpretação da formação como um processo em construção que extrapola a formação inicial e/ ou continuada realizada em contextos institucionais - não confundido este processo com a "Educação e formação ao longo da vida", que atende aos mecanismos da empregabilidade -, podendo a formação ser pensada a partir da "dialética da duração", colocando em movimento as diferentes temporalidades que constituem o sujeito professor. Nesse sentido, António Nóvoa (1992, p. 16, grifos do autor) propõe pensarmos a formação considerando os três AAA ( $A$ de Adesão, $A$ de Ação, e o A de Autoconsciência), dispondo que:

A de Adesão, porque ser professor implica sempre a adesão a princípios e a valores, a adopção de projectos, um investimento nas potencialidades das crianças e dos jovens. A de Aç̧ão, porque também aqui, na escolha das melhores maneiras de agir, se jogam decisões do foro profissional e do foro pessoal. [...] A de Autoconsicência, porque em última análise tudo se decide no processo de reflexão que o professor leva a cabo sobre a sua própria acção.

Na interpretação de António Nóvoa (1992), estes três $A A A$ são elementos básicos para a reflexão sobre a formação do processo identitário do professor, porém, considero que independente de pensarmos uma identidade, que pode suscitar a ideia de fixidez ou mesmo engessamento do profissional ou do processo de formação, os três AAA são fundamentais para refletirmos sobre o processo de formação de 
professores em geral, excedendo a procura de uma identidade, e colocando em evidência aspectos ligados à compreensão dos caminhos que produzem o processo de formação do eu profissional conectado ao eu pessoal, expandido o olhar para a dimensão da autoconsciência como profissional docente, haja vista que as mudanças ou decisões que tomamos dependem intimamente deste olhar reflexivo e consciente de si como pessoa e profissional docente.

Ampliando o pensar sobre o processo de formação de professores, António Nóvoa (2010, p. 184-187) propõe seis princípios básicos que devem constituir esse processo. O primeiro princípio contempla "o modo como ele próprio [o adulto, o professor] se forma", como este se apropria dos conhecimentos vivenciais que compõem a sua história de formação. 0 segundo princípio observa a formação como um processo de transformação individual que engloba três dimensões - a do saber (conhecimentos), do saber-fazer (capacidades) e do saber-ser (atitudes) -, perpassando desde a formação individual (autoformação) até a formação em grupo.

O terceiro princípio exige mais atenção do espaço institucional do que do sujeito em si, pois considera a articulação entre as instituições de formação e as dedicadas ao exercício da atividade profissional como essencial ao processo de formação; todavia, há o cuidado urgente de não reduzir esta articulação entre os espaços a um excesso de discurso e escassez de prática, pois existe:

[...] no espaço universitário uma retórica de 'inovação', de 'mudança', de 'professor reflexivo', de 'investigação-acção', etc.; mas a Universidade é uma instituição conservadora, e acaba sempre por reproduzir dicotomias como teoria/ prática, conhecimento/acção, etc. A ligação da Universidade ao terreno ... leva a que os investigadores fiquem a saber o que os professores sabem, e não conduz a que os professores fi- quem a saber melhor aquilo que já sabem. (NÓVOA, 1999, p. 15)

Este olhar acerca da articulação universidade/escola implica maior compromisso das instituições, delimitando suas responsabilidades e contribuições, no decorrer das etapas do processo, ampliando o diálogo com os sujeitos, e não ignorando a dimensão social e dinâmica presente "em toda e qualquer ação de formação de adultos". o quarto, quinto e sexto princípios estimulam uma postura dialogal para com o saber, explorando a sua "produção" e não o seu "consumo", o que requer do processo de formação uma face estratégica que priorize o desenvolvimento de disposições ${ }^{2}$ ou (pré)disposições necessárias à mobilização "em situações concretas" dos "recursos teóricos e técnicos adquiridos durante a formação" (NÓVOA, 2010, p. 187), colocando em movimentos alternados os princípios formativos e não recaindo na justaposição destes.

Imanente a estes prismas formativos há o transbordamento da escola e também dos professores devido as diferentes responsabilidades que estes assumiram ao longo do tempo. António Nóvoa (1999) esclarece que a docência em seu início era missão, atualmente é sobrevivência burocrática e silenciosa que, desde os anos de 1990, é atravessada por dois discursos dissonantes: o dos investigadores em educação com a reflexão sobre a prática, e o das organizações mundiais etc., que balizam seus discursos nos dados internacionais, resultando em uma ausência de conversa sobre a realidade da escola pública e da profissão docente, o que reduziu, paulatinamente, a sobrevivência profissional.

2 António Nóvoa (2009) prioriza o uso do conceito "disposições", em detrimento do conceito de competências. Esta mudança deve-se à apropriação dos estudos sobre competências pela perspectiva da educação como mercado, voltando as competências para a empregabilidade e não à emancipação ou formação cidadã. 
A formação precisa ser pensada na realidade presente, próxima à realidade escolar, “uma formação de professores construída dentro [da] profissão, isto é, baseada numa combinação complexa de contributos científicos, pedagógicos e técnicos, mas que tem como âncora os próprios professores mais experientes e reconhecidos" (NÓVOA, 1999, p. 45). O que exige tempo, para pensar, formar-se, refletir, projetar o futuro, seja este individual ou coletivo.

Ao propormos uma tentativa de reflexão que perpassa a formação de professores, suas peculiaridades e influências, lembramos também do desenvolvimento do conceito de formação, assim como de suas (re)significações apresentadas nos modelos de formação inicial como um processo de "transformação e conversão de uma pessoa em professor a partir dos traços e características que imagina possuir um professor" (HENRIQUES, 2005, p. 45). Aqui é importante observar a formação como um processo continuum que contém fases diferentes devido à estrutura curricular ou área do conhecimento, sendo a formação "um processo que tem de manter alguns princípios éticos, didácticos e pedagógicos comuns, independentemente do nível" (GARCIA, 1992, p. 55).

Ou seja, a formação inicial configura-se como o primeiro nível institucionalmente reconhecido, mas não autônomo, no que se refere a conhecimento e decisão.

Pelo contrário, as orientações adotadas ao longo da sua história encontram-se profundamente determinadas pelos conceitos de escola, ensino e currículo prevalecentes em cada época. A partir da definição de cada um destes conceitos desenvolvem-se imagens e metáforas que pretendem definir a função do docente como profissional. (GÓMEZ, 1992, p. 95)

Avançando no processo de construção do conceito de formação, encontra-se a formação reflexiva sinalizada por Dewey, em 1933, ao defender o ensino reflexivo, e por consequência, um processo de formação do professor que possibilita a reflexão, que procura deslocar o professor da posição de reprodutor. No cerne deste movimento está o retorno do sujeito, sua voz, uma recondução do olhar geral ao particular que, no campo das ciências educacionais, se configura como uma mudança paradigmática.

Seguindo este movimento de mudança, a formação de professores tenciona uma nova epistemologia de pesquisa e de formação, encontrando eco nas abordagens (auto)biográficas que indicam uma ruptura com as clássicas perspectivas disciplinares, pois:

[...] são trabalhos que buscam, na racionalidade instituinte, a possibilidade de afirmação da pesquisa e da formação com um olhar sobre o sujeito, em uma autoprodução profunda e dialeticamente articulada às complexas dinâmicas da vida pessoal e coletiva. (BRAGANÇA, 2008, p. 69)

As histórias de vida e formação são também um exemplo para pensarmos a formação de professores, em especial a de adultos, e tem estado muito presente no contexto dos estudos do campo educacional. A inserção das abordagens (auto)biográficas e das histórias de vida, no campo da Educação, acontece dentro do movimento de ruptura paradigmática realizado nas ciências humanas em resposta à forte generalização, à ideia de neutralidade etc., características do modelo positivista de construção do conhecimento. Nessa direção, o nascimento dessa perspectiva na pesquisa, deve-se à sociologia, por meio de discussões acerca do método biográfico "no final do século XIX na Alemanha como alternativa à sociologia positivista" (NÓVOA; FINGER, 2010, p. 22), sendo amplamente difundido entre os anos de 1920 e 1930 pelos sociólogos americanos da Escola de Chicago. Porém, nas três décadas seguintes, o método biográfico, no contexto da Sociologia, caiu em desuso e só reapareceu nos anos de 
1980, com as mesmas lacunas procedimentais e epistemológicas que causaram o hiato.

No cerne do processo de reaparição do método biográfico está o texto de Franco Ferrarotti (2010) - Sobre a autonomia do método biográfico, 1979, $1^{\circ}$ publicação: Sociologie de la Connaissance. Neste texto, Ferrarotti critica o uso do método biográfico pela sociologia, falando de suas "metamorfoses", como: o silenciamento da interação observador-observado; a quantificação do método via a justaposição de biografias; a redução do método biográfico ao fato, à exemplificação, ${ }^{3}$ à ilustração. Desse modo, os elementos principais do método biográfico, "a subjetividade e a exigência antinomotética" (FERRAROTTI, 2010, p. 39) se perdem quando este é submetido à objetividade tradicional, para atender a comunidade científica.

Assumir a subjetividade inerente ao método biográfico foi (para os sociólogos), e é (para nós), a tarefa mais dificil porque engloba questões sobre o grau de representatividade da biografia individual. A validade heurística da biografia individual justifica o seu valor via o conceito de "práxis humana", de modo que "o indivíduo não é um epifenômeno do social ... [este] apropria se dele, mediatiza-o, filtra-o e volta a traduzi-lo, projetando-se numa outra dimensão, que é a dimensão psicológica da sua subjetividade" (FERRAROTTI, 2010, p. 44). Abandona-se aqui a neutralidade e a objetividade de ambos os sujeitos envolvidos no processo de construção e desenvolvimento do método biográfico e assume-se a perspectiva de interação entre sujeitos, o ato de escuta, e o espaço-tempo da construção narrativa precisa ser considerado como contexto de interação social.

3 Ferrarotti (2010) crítica a exemplificação no sentido de que a história de vida entra no processo de construção do estudo como um modo de corroborar uma informação anterior. Neste caso, a história de vida fica em segundo plano. É esta secundarização que Ferrarotti considera escandalosa.
Nesse sentido, "toda entrevista biográfica é uma interação social completa, um sistema de papéis, de expectativa, de injunções de normas e de valores implícitos" (FERRAROTTI, 2010, p. 46). Ou seja, a totalização individual do mundo social que permeia o sujeito não é realizada pelo olhar direto deste sujeito e sim pela mediação propiciada pelo contexto social no qual o sujeito está inserido. A ação exotópica do sujeito só é possivel por causa do contexto social que o inscreve. É nesse processo de mediação entre social (global) e singular (individual) que os grupos mais próximos do sujeito (grupos primários) são os mais interessantes à construção da narrativa biográfica. Os espaços mediadores mais importantes são os grupos restritos, família, grupos de trabalho, de vizinhança, de classe, etnia etc., grupos que "participam simultaneamente da dimensão psicológica dos seus membros e na dimensão estrutural de um sistema social" (FERRAROTTI, 2010, p. 54). Esta percepção induz a ideia de uma construção narrativa de grupo.

Antonio Bolivar (2014), com um olhar mais atual para as nuanças das abordagens (auto) biográficas, recorda a questão - já citada anteriormente por Ferrarotti - da legitimação e justificação de conhecimento cuja procedência deve-se a uma história de vida singular/subjetiva. Para este autor, como estamos falando de produção de conhecimento, realização de pesquisas no campo educacional, devemos ir em direção a caminhos onde encontraremos abordagens genealógicas, arqueológicas ou históricas, pois, estando fora dos pressupostos modernos, vivendo em tempos de modernidade tardia, e considerando o contexto da produção de conhecimento, "no es la epistemología la que debe determinar la metodología, pues no se liga metodología y paradigma, ni hay oposición entre ellos (mixed methods)"4 (BOLIVAR,

4 "não é a epistemologia que deve determinar a metodologia, pois não se liga metodologia e paradigma, não há oposição entre eles (há uma mistura de métodos)". 
2014, p. 114). A investigação (auto)biográfica, segundo Bolivar (2014, p. 117) está inscrita no paradigma fenomenológico "que sostiene que la realidad es construída socialmente mediante definiciones individuales o colectivas de una determinada situación", ${ }^{5}$ não limitando as narrativas das histórias de vida (orais ou escritas) à simples coleta de dados para o estudo.

Ratificando a proposição de Franco Ferrarotti (2010), Antonio Bolivar (2014) coloca que os estudos que têm como base os modos e traços da investigação (auto)biográfica tendem a trazer à emersão os processos de socialização que constituem os sujeitos envolvidos no estudo, imbricando os espaços por eles ocupados, de modo a pensarmos os estudos como uma construção híbrida; o compósito entre as narrativas/relatos de vida dos sujeitos, contextos social, histórico, político etc., formam uma rede de sentidos que conecta o sentido singular ao plural. Desse modo, o diálogo e a presença central das histórias de vida, nos estudos que envolvem a formação de professores, figuram um cenário de construção de conhecimento sobre o tema que traz novos elementos metodológicos e epistemológicos, sinalizando para uma nova epistemologia de formação que procura romper com a perspectiva clássica disciplinar de formação, pois, segundo Couceiro ${ }^{6}$ (2002 apud BRAGANÇA, 2012, p. 72)

[...] o objeto das histórias de vida, em ciências da educação, é a formação/autoformação, na medida em que nos permitem conhecê-las melhor e os seus processos. De algum modo as histórias de vida são uma 'mediação' para a formação. Não no sentido de as considerar como uma técnica de formação, mas como uma abordagem que produz, ela própria, um certo tipo

5 "que sustenta que a realidade é construída socialmente mediante definições individuais ou coletivas de uma determinada situação".

6 COUCEIRO, Maria do Loureto Paiva. O porquê e para que do uso das histórias de vida. In: MALPIQUE, Manuela. Histórias de vida. Porto: Campo das Letras, 2002. p. $155-160$. de formação e um certo tipo de conhecimento. Ou seja, as histórias de vida influenciam a natureza da formação que se produz, introduzindo mesmo uma ruptura epistemológica no conceito de formação.

Pierre Dominicé (2010) corrobora este olhar, apresentando uma nova dimensão de formação que coloca em diálogo o tempo presente como formador e o pretérito como luz para enxergar significações pensadas como naturais, pois "a história de vida é outra maneira de considerar a educação. Já não se trata de aproximar a educação da vida, como nas perspectivas da educação nova ou da pedagogia ativa, mas de considerar a vida como o espaço de formação" (DOMINICÉ, 2010, p. 201). É inegável que as abordagens (auto)biográficas têm como prioridade o papel do sujeito na sua formação, gerando uma autonomia e demandando um redimensionamento do conceito de formação.

Dialogando com Philip W. Jackson (1999), a partir de sua proposição sobre as aprendizagens implícitas, é possível considerar que a nossa formação profissional não está restrita aos elementos formativos explícitos ao processo, como conteúdo científico, pedagógico, formas de avaliação etc., mas extrapola esta dimensão "objetiva”, espaço-temporal, reconhecida social e institucionalmente, chegando a um conhecimento implícito, que deixa marcas indeléveis em nossa atuação profissional, na constituição de nossa subjetividade, de modo que:

[...] en la raíz de mi incertidumbre sobre cómo interpretar mi persistente recuerdo de la señora Henzi ${ }^{7}$ y los sentimientos mezclados que lo acompañan, subyace la profunda sospecha de que lo que aprendíamos em su clase no se limitaba en modo alguno al álgebra. Al mismo tiempo, sin embargo, como ya lo reconocí, no puedo describir ese aprendizaje adicional (si es que se lo puede llamar asi), del mismo modo en que puedo describir mi conocimiento de álgebra,

7 Professora de álgebra de Philip Jackson. 
como tampoco puedo afirmar con seguridad que em realidad existió. ${ }^{8}$ (JACKSON, 1999, p. 25)

Seguindo os caminhos incertos do rememorar admitidos por Philip Jackson (1999), percebo que os sentidos implícitos que perpassam a nossa formação são produzidos pela permanente conexão entre e com os contextos sociais, institucionais, familiares, que nos atravessam, sendo a constituição da docente que sou, uma construção historicamente construída e aberta à reflexão/alteração e afetada por questões que transcendem a "objetividade" do processo de ensino e aprendizagem, mas nem por isso aspectos menos importantes ou menos potentes em sua dimensão formadora. Como possibilidade para ampliar este olhar para as experiências singulares de formação e os cruzamentos entre o pessoal e o institucional, a partir das narrativas das experiências de formação dos licenciandos em física sobre as disciplinas pedagógicas, apresentamos, no próximo item, o conceito de experiência discutido por Walter Benjamin (2012) em diferentes momentos e textos de sua autoria.

\section{O conceito de experiência e a} formação pedagógica como uma experiência de formação

A palavra experiência é um substantivo feminino e possui diferentes significados no dicionário, como: "ato de experimentar. Ensaio. Tentativa. Conhecimento adquirido por prática, estudos, observação etc.; experimentação. Homem de experiência: homem conhecedor das

8 "na raiz de minha incerteza sobre como interpretar minha persistente recordação da senhora Henzi e os sentimentos mesclados que o acompanham, subjaz a profunda suspeita de que o que aprendíamos nas suas aulas não se limitava de modo algum à álgebra. Ao mesmo tempo, sem engano, como já reconheci, não posso descrever essa aprendizagem adicional (se é que se pode chamar assim), do mesmo modo que posso descrever meu conhecimento de álgebra, como tampouco posso afirmar com segurança que na realidade existiu". coisas da vida"..$^{9}$ Estes significados são ressignificados cotidianamente, a partir das nossas ações cotidianas, em especial, como docentes. Em consonância com este olhar, há, nos estudos realizados por Walter Benjamin (2012), com destaque para dois textos: "Experiência e pobreza" e o "Narrador - Considerações sobre a obra de Nikolai Leskov", uma crítica densa à automatização das experiências e à baixa cotação de experiências narráveis.

O primeiro texto, "Experiência e pobreza", foi escrito em 1933. É um texto pequeno, de no máximo seis páginas, que começa com a fábula do vinhateiro em seu leito de morte que deixa aos seus filhos um 'conselho'. - Há um tesouro oculto nos vinhedos. Basta desenterrá-lo! Os filhos cavaram e nada encontraram, entretanto, no período da colheita, as vinhas produziram mais uvas que qualquer outra da região -. A partir desta fábula, Benjamin (2012) relata um tipo de experiência, pois o que o pai deixou não foi um tesouro, mas uma "certa experiência" que foi transmitida em seu leito de morte. Neste contexto, Benjamin (2012) apresenta uma primeira perspectiva para o conceito de experiência, pois, "sabia-se também exatamente o que era a experiência: ela sempre fora comunicada pelos mais velhos aos mais jovens (BENJAMIN, 2012, p. 123). Após esta acepção acerca da experiência, Benjamin (2012, p. 123) segue perguntando se alguém, na primeira metade do século XX, ainda faz uso dessas experiências? Responde que não e acrescenta: "Está claro que as ações da experiência estão em baixa".

Uma das consequências de baixa da experiência deriva da primeira grande guerra, que

9 Exemplo de significados: ato de experimentar. Ensaio. Tentativa. Conhecimento adquirido por prática, estudos, observação, etc.; experimentação. Homem de experiência - Homem conhecedor das coisas da vida. Extraído de: Dicionário Priberam da Língua Portuguesa [em linha], 2008-2013. Disponivel em: <https:// www.priberam.pt/dlpo/experi\%C3\%AAncia>. Acesso em: 06 ago. 2017. 
foi uma experiência tão impactante e diferente que os soldados voltaram mudos, pobres de experiências transmissiveis. Neste sentido, a historiografia da guerra, a ascensão da técnica - produto do desenvolvimento do modo de produção capitalista -, corroboraram para que a experiência terrivel da guerra e a comunicação das experiências, inclusive em uma de suas importantes funções de transmitir conselhos, se tornassem inviáveis, pois só restou àquela geração a "lembrança das nuvens do céu".

Esta imagem construída por Walter Benjamin (2012) figura a dimensão traumática dos acontecimentos que atropelaram a fragilidade humana, sob esse céu de guerra e chão de vidro. $O$ que foi oferecido a esta geração e seus descendentes foi, e é uma "galvanização" constante de nossas experiências. Desde então, vivenciamos uma outra perspectiva de experiência, um tipo de experiência que não nos vincula ao nosso patrimônio cultural, como nos diz Leandro Konder (1988), ficamos pobres, “e essa pobreza não [é] apenas pobreza em experiências privadas, mas em experiências da humanidade em geral. Surge assim uma nova barbárie" (BENJAMIN, 2012, p. 125).

A partir desse trecho, Benjamin (2012) inicia a apresentação de um tipo positivo de barbárie, que, na minha leitura, é positivo porque as pessoas do século XX estavam vivendo experiências, mesmo que sejam experiências de tipo Erlebnis. A Erlebnis é a "característica do indivíduo solitário" (GAGNEBIN, 2012, p. 9), "é a vivência do indivíduo privado, isolado; é a impressão forte, que precisa ser assimilada às pressas, que produz efeitos imediatos... é a fantasmagoria do ocioso" (KONDER, 1988, p. 72), e é barbárie porque não é construída pelos indivíduos, mas sim a partir de "tábula rasa", sem elo com as experiências vivenciadas anteriormente pelos indivíduos.

O último parágrafo do ensaio "Experiência e pobreza", Benjamin (2012) inicia afirmando que "Ficamos pobres. Abandonamos, uma a uma, todas as peças do patrimônio humano, tivemos que empenhá-las muitas vezes a um centésimo do seu valor para recebermos em troca a moeda miúda do atual". Sim, estamos pobres! Porém, vivemos sob a barbárie positiva, que segundo Benjamin (2012, p. 128), nos faz caminhar para a frente "sem olhar nem para a direita e nem para esquerda", e caminhando podemos pensar em um outro tipo de experiência - que parte das "novas coisas ruins" - e se aproxima de uma Erfahrung, que é outra perspectiva de experiência proposta por Benjamin (2012), no ensaio "O narrador".

"O narrador - considerações sobre a obra de Nikolai Leskov" foi escrito em 1936 e, para Jeanne Marie Gagnebin (2013, p. 56), ele "retoma vários esboços nos quais Benjamin trabalhava desde os anos de 1920 e que ele recoIheu sob a égide de Nicolas Leskov, autor russo da segunda metade do século XIX sobre o qual a revista Oriente et Occident the encomendou um artigo". Benjamin inicia o ensaio esclarecendo que mesmo a palavra "narrador" sendo próxima do grande público, escrever sobre ela não significa aproximá-la das pessoas, mas, sim, mostrar o quão distante dos grandes narradores estamos.

Entretanto, por que estamos distantes dos grandes narradores? Primeiro porque, para enxergar "os traços grandes e simples" de um narrador, é necessário, segundo Benjamin (2012, p. 213), que o observador esteja:

[...] localizado numa certa distância apropriada e num ângulo favorável. Essa distância e esse ângulo de observação nos são impostos por uma experiência quase cotidiana. É a experiência de que a arte de narrar está em vias de extinção. São cada vez mais raras as pessoas que sabem narrar devidamente. [...]. É como se estivéssemos sendo privados de uma faculdade que nos parecia totalmente segura e inalienável: a faculdade de intercambiar experiências. 
E, segundo, porque não temos mais experiências comunicáveis, não há o que narrar. Jeanne Marie Gagnebin (2013) sinaliza que estas experiências estão implicadas em uma temporalidade comum a diferentes gerações, o que supõe o compartilhamento de experiências, a retomada pela memória destas experiências que são ouvidas, memorizadas e recontadas dentro de uma forma de comunicação, uma prática comum que se aproxima de uma verdadeira formação para os sujeitos que constroem este espaço-tempo partilhado.

Sendo a Erfahrung uma composição coletiva e o ciclo narrativo uma das formas de sobrevivência destas experiências às intempéries do espaço-tempo moderno, cabe perguntar: como é possivel construir uma experiência coletiva nos dias atuais em que o modo de produção artesanal e coletivo foi substituído pelo modo de produção capitalista que isola o sujeito e fragmenta o processo produtivo? Como compor uma experiência que seja rememorada entre gerações? Em quais espaços, atualmente, é possivel rememorar e narrar? Benjamin (2012) não dá respostas, mas, na parte final do ensaio "O narrador", ele impele à reflexão em torno da relação entre o narrador e a sua matéria-prima - a vida humana.

Tentando pensar as possiveis conexões entre a matéria-prima - vida - e os processos de formação como espaços-tempos de construção de experiências com sentido de Erfahrung, experiências de formação que possibilitem a narração em toda a sua dimensão articuladora de sentidos das múltiplas histórias de formação em contextos institucionais, propomos olhar a experiência de licenciandos em física com as disciplinas pedagógicas cursadas, ao longo do curso de licenciatura em física, como uma narrativa de experiência que transpassa o singular e o coletivo, os sujeitos e as instituições de formação, que transcende a dimensão explícita das experiências narradas e que compõe processos de formação múltiplos e abertos.

\section{As narrativas e sua leitura}

Como sinalizamos no início deste texto, o conceito de formação como processo conecta as diferentes temporalidades; todavia, não podemos esquecer que o passado é prenhe de futuro, logo, retomar o passado, restaurar uma “origem não pode cumprir-se através de um suposto retorno às fontes, mas unicamente, pelo estabelecimento de uma nova ligação entre o passado e o presente" (GAGNEBIN, 2013, p. 16). Se o reencontro com o passado é essencial, este também não é possível em sua plenitude. Assim, a mediação via lembrança, o estudo dos signos que herdamos e a rememoração se configuram como um movimento de apropriação restaurativa e de reprodução do passado acessivel, que é sempre inacabado e incompleto, podendo ser transformado no presente; rememorar o passado não implica somente restaurá-lo, “mas também uma transformação do presente tal que, se o passado perdido aí for encontrado, ele não fique o mesmo, mas seja ele também, retomado e transformado" (GAGNEBIN, 2013, p. 16).

A transformação do passado no presente e do próprio presente ocasiona uma coincidência entre os tempos históricos que no objeto e a partir dele se totaliza. O objeto histórico e a obra (experiência narrada, signos etc.) ficam irredutiveis à cronologia histórica linear e causal, entre o antes e o depois. Este movimento totalizante que é circunscrito ao objeto histórico, por ele realizado e nele contido, abrindo mão de uma ordem universal, tem em seu cerne a fuga do antagonismo entre a concepção mecânica e orgânica, entre o modelo físico e o biológico da historiografia tradicional.

Nesse sentido, a noção de origem proposta por Walter Benjamin (2016) carrega dois traços 
importantes. Um se relaciona com a possibilidade de escrita da história dos vencidos opondo-se ao modelo determinista e causal da historiografia, com seu tempo vazio, homogêneo, a priori e infinito -, e outro com a temporalidade histórica, no sentido de capturar a intensidade da obra, da história natural humana.

A Ursprung designa, portanto, a origem como salto (Sprung) para fora da sucessão cronológica niveladora à qual uma certa forma de explicação histórica nos acostumou. Pelo seu surgir, a origem quebra a linha do tempo, opera cortes no discurso ronronante e nivelador da historiografia tradicional. (GAGNEBIN, 2013, p. 10, grifos da autora)

Nesta proposição de origem, como salto que circunda a experiência histórica em um espaço sem bordas, há uma apropriação do conceito de mônada do filósofo Leibniz. "Origem, enteléquia, mônada: trata-se sempre da mesma ideia de totalização a partir do próprio objeto e nele" (GAGNEBIN, 2013, p. 11). Gottfried Wilhelm Leibniz em seu texto Monadologia apresenta a ideia de mônada como oposição a filosofia cartesiana do século XVII, que desconsiderava "as percepções que não são apercebidas" (LEIBNIZ, 2007, p. 2) pela razão. A mônada é como uma substância simples, sem partes, "verdadeiro átomo da natureza", que só pode começar por criação e acabar por aniquilamento; as mônadas "não possuem janelas através das quais algo possa entrar ou sair" e modificações só são possíveis internamente, seguindo o próprio movimento interno de mudanças e permanências, acarretando a inexistência de duas mônadas iguais. As mônadas, para Leibniz, contêm as percepções e suas modificações, e, em Benjamin, elas "podem ser entendidas como pequenos fragmentos de histórias que juntas exibem a capacidade de contar sobre um todo, muito embora esse todo possa também ser contado por um de seus fragmentos" (ROSA et al, 2011, p. 203).
Benjamin (2016), ao pensar a ruptura histórica a partir da "origem", vê na mônada a possibilidade de romper com os limites entre passado e futuro, pois para ele "a ideia é uma mônada. O ser que nela penetra com a sua pré e pós -história mostra, oculta na sua própria, a figura abreviada e ensombrada do restante mundo das ideias... [e] em cada uma delas estão indistintamente presentes todas as demais" (BENJAMIN, 2016, p. 36).

É devido às especificidades das mônadas, em especial sua constituição parte-todo, simples-composto, à sua potência para realizarmos saltos para fora do naturalizado, possibilitando a articulação entre as experiências individuais do sujeito e os espaços-tempos sociais mais amplos que ele constrói, "porque o 'eu' que nelas se diz não fala somente de si, mas também porque deve ceder lugar a algo outro que não si mesmo (GAGNEBIN, 2013, p. 80), que optamos por trazer nesta parte do texto as mônadas que são partes das narrativas de histórias de vida de licenciandos de uma universidade federal do Estado do Rio de Janeiro.

Porém, antes do primeiro contato com as mônadas, é preciso entender como elas foram possiveis, entender um pouco do processo de construção das narrativas e das mônadas.

A escuta das narrativas aconteceu no contexto de uma entrevista narrativa que é "uma forma de entrevista não estruturada, de profundidade, com características específicas" (BAUER; JOVCHELOVITCH, 2002, p. 95) que limita o proponente da entrevista e amplia os espaço-tempos para o convidado contar sua história. Ao narrar sua história, cada um narra-se antes para si (como processo do pensamento) e materializa o mesmo ao externo (como palavra), a mediação existente neste processo externo-interno-externo, é um momento subjetivo (auto)formativo.

A entrevista narrativa, apresentada por Martin Bauer e Sandra Jovchelovitch (2002), é 
uma ampliação/adaptação de uma proposta realizada por Schütze, no âmbito de uma pesquisa com soldados de guerra. Sua organização consiste em quatro fases principais, que são: iniciação (apresentação do tópico inicial entre os sujeitos envolvidos na entrevista); narração central (momento em que o convidado para a entrevista inicia o fluxo de sua narrativa; esta deve acontecer sem interrupção, pois uma vez que a narrativa foi iniciada ela só é interrompida quando o convidado sinaliza que encerrou); fase das perguntas (que consiste na possibilidade de conversa entre o convidado e o anfitrião) e a fala conclusiva (momento que não é gravado, e é permitido perguntas do tipo "por quê?").

As mônadas são frutos de leituras das narrativas das histórias de vida construídas no contexto de entrevistas narrativas individuais, que foram realizadas com dois licenciandos em física que cursavam o último período do curso; no decurso da leitura, nós selecionamos momentos das narrativas que melhor pudessem dialogar com questões importantes, relacionando formação, experiência e contextos institucionais. As entrevistas tiveram como tópico inicial deflagrador das narrativas as experiências de formação dos sujeitos, sem demarcação de tempo, etapa ou nível de formação.

Desse modo, as mônadas configuram-se como pequenos fragmentos da história de vida e formação dos licenciandos em física, que saltam do todo da narrativa e remetem a aspectos mais amplos e estruturantes do processo de formação inicial de professores de física para atuar no ensino médio. Maria Inês Petrucci Rosa e Tacita Ansanello Ramos (2015, p. 147) consideram que as mônadas, metodologicamente falando, "são excertos das transcrições das entrevistas que são recriadas mediante textualização, produção de um título e edição. Expressam-se como pequenas crônicas, historietas com início e final geralmente aberto", deixando ao leitor a possibilidade de descortinar a nossa leitura, que é singular, mas não única, e muito menos universalizante. Ratificamos que as mônadas foram construídas como uma leitura de pontos emblemáticos das narrativas dos licenciandos, porém não especificamos o sujeito da narrativa (nome do licenciando, mesmo que seja fictício) que possibilitou a criação da mônada; a opção por não nomear os sujeitos teve como objetivo colocar foco no movimento parte-todo, singular-coletivo, característico da constituição da mônada. Para cada mônada, foi criado um título delineador de sua ideia, ponto de diálogo com os objetivos deste texto e estes títulos são frases que fazem parte das mônadas.

\section{Mônada 1 - Profissão de humanas}

Primeiro... eu fiz psicologia da educação com a M.... e... foi uma disciplina bem diferente... bem... para te fazer pensar em coisas que você... talvez... provavelmente... nunca tenha pensado na física... ou na vida... mas... ela não é uma disciplina muito conteudista.... digamos assim... ela era uma coisa mais reflexiva... e as disciplinas de educação que eu fiz... PPE [componente curricular Pesquisa e Prática Pedagógica] um... dois... três... foi bem divisor de águas porque eu lembro que ... e... isso foi muito marcante para mim... pensar na profissão docente em fisica como uma profissão de humanas... e isso foi um divisor de águas... tipo... eu nunca tinha pensando em um docente... em mim como um profissional de humanas... e isso é bem importante... isso foi em PPE um... talvez... umas das coisas mais enriquecedoras nessa minha formação tenha sido produção um... com certeza... foi uma das disciplinas que a gente mais lia... realmente... eu li... a gente discutia muitas coisas... que o pessoal chama de referencial teórico... e coisas realmente... assim... teorias... realmente um pouco mais embasadas... não só 
achismos e tudo mais... e foi bem esclarecedor e inovador... e eu diria que por causa dessas coisas.

\section{Mônada 2 - Fornecer ferramentas}

A gente sempre ouve falar que o professor tem que... você imagina... é o senso comum que diz que o professor é um profissional diferenciado... o professor lida com os alunos de uma maneira diferente... que o professor... não sei... de alguma forma o professor consegue... conseguiria extrair coisas boas do alunos e tal... só que você ouve isso... você fala isso... mas eu não tinha nenhum respaldo para dizer porque isso era importante... ou diferenciar isso do ensino tradicional... do ensino transmissivo... ou por que isso é ruim... assim... eu sempre tive uma visão da licenciatura muito a partir do achismo... e essas disciplinas... primeiro elas produziram muitas reflexões que eu jamais teria tido em torno da atividade docente.... me propiciaram ver muitas coisas e questionar muitas coisas que a gente questiona naturalmente... mas com embasamento... a gente sabe que as estratégias de ensino por acúmulo ou repetição... tipo kumon... ou mesmo o ensino transmissivo que o aluno vai fazer uma prova e tal... mas... por que é ruim?...e até então... eu não sabia responder isso... e dizia sei lá... as pessoas não devem aprender direito... não sei... então teve esse detalhe de me propiciar o contato com esse conhecimento... mas também teve algumas coisas que foram importantes no sentido de fornecer ferramentas... e isso a disciplina de produção um com certeza... ferramentas para a sala de aula.... isso foi bem importante.

\section{Mônada 3 - Depois de bastante tempo}

Eu tive muito professor bom... mas também tive muito professor ruim... e não é porque eu não passei na matéria que o professor foi ruim... mas sim... o jeito... enfim... didática dele... eu posso não passar na matéria do professor e ele ser um excelente professor... e eu tenho que reconhecer isso e tem gente que não é muito bom $e$ você e passa e acha que é muito bom... eu acho que para fechar assim... foi breve... mas eu acho que para fechar... toda a minha graduação... esses professores ruins... enfim... me ensinaram a não ser como eles... então... o que eu quero seguindo a carreira de professora... é não ser como eles... isso é o que eu tiro de máxima da minha graduação... eu pretendo sim... seguir... se eu for um pouquinho do que a professora A. é.. um pouquinho do que a professor Ú. é... eu acho que já vai estar sendo demais... vai estar sendo muito legal... e eu acho que eu saio daqui... depois de bastante tempo... porque foi um curso muito longo... eu saio daqui sabendo exatamente o tipo de profissional que eu não quero me espelhar... e eu acho que isso é mais importante... é isso.

$$
* \star *
$$

Na mônada 1 - Profissão de humanas - é interessante perceber o espanto do licenciando ao ser comunicado que a profissão docente em física o identifica com o profissional de humanas, sendo este o que ele imagina que é ser profissional de humanas, ou seja, um profissional que reflete, que se implica com o contexto de sua formação e prática, aspectos que ele não considerou necessários à sua formação como físico. Em relação à experiência com as disciplinas pedagógicas, o licenciando a observa como uma experiência que se configura como um "divisor de águas" porque, além de propiciar o diálogo com a ideia de que professor é um profissional de humanas, estas disciplinas também foram fundamentais e enriquecedoras - em especial as disciplinas ministradas por docentes do instituto de física, como Produção de Materiais Didáticos para o 
Ensino de Física I (produção um) - porque nelas os licenciandos discutiam "muitas coisas... que o pessoal chama de referencial teórico... e coisas realmente... assim... teorias... realmente um pouco mais embasadas... não só achismos e tudo mais... e foi bem esclarecedor e inovador eu diria... por causa dessas coisas". Neste trecho podemos perceber, com a ajuda de Ferraroti (2010) e Jackson (1999), como as múltiplas mediações que o contexto socioinstitucional de formação propicia, produzem aprendizagens implícitas na forma de se relacionar com o saber, neste caso, com a física e com o ensino de física, que se descobre humano.

A experiência com as disciplinas pedagógicas reaparece na mônada 02 - Fornecer ferramentas - sob um aspecto formativo e construtivo, no que se refere à ideia de formação de professores; a experiência do licenciando foi marcante no sentido de que há uma transição entre a "visão da licenciatura ...a partir do achismo" para um olhar norteado pelos referenciais teóricos de formação, aprendizagem etc. Há na mônada 2 a proposição de que uma das funções das disciplinas pedagógicas, no processo de formação de professores de física, está ligada ao fornecimento de "ferramentas para a sala de aula"; esta associação entre as disciplinas pedagógicas e o fornecimento de ferramentas pode ser vista como um reflexo do modo de formação do físico e sua dimensão instrumental. A graduação em Física fornece ferramentas para que o físico possa fazer a ciência Física acontecer e o licenciando pensa o processo de formação em licenciatura também como a soma de ferramentas para exercer a docência e não como um processo de formação no qual temos contato com os modos de ser e fazer docente, e a partir destes, permeados pelo contexto escolar e sujeitos que o compõem, criar a ação docente cotidiana. Embora o licenciando tenha reconhecido a importância das disciplinas pedagógicas, ele as significou dentro de uma concepção instrumental, como sinalizado por Angel Pérez Gómez (1992), mantendo a percepção hierárquica entre o conhecimento científico básico aplicado da formação (a formação de bacharelado) e as derivações técnicas da prática profissional, ou seja, a identificação da formação docente como uma formação técnica e instrumental. É interessante observar como o processo de formação, no caso, uma formação socioinstitucional, sempre transborda do aspecto puramente conteudista da disciplina, para aspectos que também significam a própria relação do aprender e do ensinar

A mônada 3 - Depois de bastante tempo - é emblemática e dialoga também, como na mônada 2, diretamente com as aprendizagens que extrapolam os conteúdos disciplinares no contexto e espaço-tempo da sala de aula, promovendo processos de ensino e aprendizagem implícitos sobre o que é ser um bom ou mau professor. Nesse sentido, o licenciando aponta a dicotomia professor bom e professor ruim e ratifica que de "toda a minha graduação... esses professores ruins... enfim... me ensinaram a não ser como eles... então... o que eu quero seguindo a carreira de professora... é não ser como eles... isso é o que eu tiro de máxima da minha graduação...eu pretendo sim... seguir... se eu for um pouquinho do que a professora A. é.. um pouquinho do que a professor Ú. é... eu acho que já vai estar sendo demais... vai estar sendo muito legal... e eu acho que eu saio daqui... depois de bastante tempo... porque foi um curso muito longo... eu saio daqui sabendo exatamente o tipo de profissional que eu não quero me espelhar... e eu acho que isso é mais importante". Fica para nós, com o auxílio das reflexões de Walter Benjamin (2012; 2016), a percepção de que nos constituímos professores através de uma leitura e interpretação de situações às quais atribuímos os mais variados sentidos, os quais não são estáticos nem cris- 
talizados, e que a possibilidade de narrá-los e inseri-los em nossa trajetória de formação, permite sua ressignificação, e sua transformação em uma experiência, neste caso, uma experiência de formação.

\section{As experiências de formação e os cruzamentos entre o individual e o institucional}

As experiências de formação que emergem das três mônadas e da leitura que realizamos delas são unânimes no diálogo com a percepção acerca dos tipos de experiências discutidos por Walter Benjamin, em especial a construção de experiências que se aproximam de Erfahrung, de experiências de formação que possibilitem a narração em espaços comuns, que aparecem como constituintes do processo, que não são desintegradas e que produzem um saber que pode ser narrado, ampliado por outras vozes e leituras e que resiste à automatização das ações cotidianas, inclusive as docentes, seja nos processos de formação ou na prática docente. A percepção dos licenciandos sobre a docência em física entra em processo de transição a partir do contato com as disciplinas pedagógicas e com os diferentes modos de exercer a atividade docente, são experiências que dialogam com aprendizagens implícitas que nos constituem como docentes hoje e amanhã, ficando em aberto os saberes que se transformaram em conselhos, como manifesto por Walter Benjamin (2012), com a fábula do vinhateiro. Há um tesouro oculto nos vinhedos [nas salas de aula]. Basta desenterrá-lo, e narrá-lo!

Outro aspecto que desejamos trazer para pensarmos o processo de formação de professores de física é a contribuição das Abordagens (Auto)biográficas que possibilitam uma aproximação entre os espaços-tempos de formação e os sujeitos, com suas formas de com- preender e significar, em especial, a formação inicial. A imersão nas histórias de vida e formação, neste estudo, e também no processo de formação de professores de física, pode ser enxergada como uma aproximação deste processo a aspectos humanos, mais subjetivos, procurando construir experiências de formação em física que nos conectem com o nosso eu pessoal, profissional, social, e que conectem a ciência Física à dinâmica social que nos atravessa, constitui e constrói enquanto sujeitos de nossas experiências cotidianas, ao mesmo tempo individuais e coletivas.

\section{Referências}

ARAUJO, Renato Santos; VIANNA, Deise Miranda. A história da legislação dos cursos de licenciatura em Física no Brasil: do colonial presencial ao digital a distância. Revista Brasileira de Ensino de Física, v. 32, n. 4, p. 4403-1-4403-12, 2010.

BAUER, Martin W.; JOVCHELOVITCH, Sandra. Entrevista narrativa. In: BAUER, Martin W.; GASKELL, George. (Orgs.). Pesquisa qualitativa com texto, imagem e som: um manual prático. Tradução de Pedrinho A. Guareschi. 9. ed. Petrópolis, RJ: Vozes, 2002. p. 90-113.

BENJAMIN, Walter. Origem do drama trágico alemão. Edição e tradução João Barrento. 2. ed.; 1 reimp. Belo Horizonte: Autêntica, 2016.

Magia e técnica, arte e política: ensaios sobre literatura e história da cultura. Tradução de Sérgio Paulo Rouanet; prefácio de Jeanne Marie Gagnebin. 8. ed. revista. São Paulo: Brasiliense, 2012. (Obras Escolhidas, 1).

BOLÍVAR, Antonio. A expressividade epistêmicometodológica da pesquisa (auto)biográfica. In: ABRAHÃO, Maria Helena Menna Barreto; BRAGANÇA, Inês Ferreira de Souza; ARAÚJO, Mairce da Silva. (Orgs.). Pesquisa (auto)biográfica, fontes e questões. Curitiba: CRV, 2014. p. 113-127.

BRAGANÇA, Inês. F. de Souza. Histórias de vida e formação de professores/as: um olhar dirigido à literatura educacional. In: SOUZA. Elizeu Clementi- 
no de.; MIGNOT, Ana. C. Venancio. (Orgs.). Histórias de vida e formação de professores. Rio de Janeiro: Quartet; Faperj, 2008. p. 65-88.

Histórias de vida e formação de pro-

fessores: diálogos entre Brasil e Portugal. Rio de Janeiro: EDUERJ, 2012.

BRASIL. Medida Provisória $\mathbf{N}^{\circ} \mathbf{7 4 6}$, de 22 de setembro de 2016. Brasília, 2016. Disponível em: <http:// www.planalto.gov.br/ccivil_03/_Ato2015-2018/2016/ Mpv/mpv746.htm>. Acesso em: 13 fev. 2017.

. Lei no 5.692, de 11 de agosto de 1971. Fixa Diretrizes e Bases para o ensino de $1^{\circ}$ e 20 graus, e dá outras providências. Diário Oficial da União - Seção 1, p. 6377, Brasília, 1971. Disponível em: <http:// www2.camara.leg.br/legin/fed / lei/1970-1979/lei5692-11-agosto-1971-357752-publicacaooriginal-1-pl. html>. Acesso em: 16 nov. 2017.

Lei n. 5.540 de 28 de novembro de 1968. Diário Oficial da União - Seção 1, p. 10369 (Publicação Original). Disponível em: <http://www2.camara.leg.br/legin/fed/lei/1960-1969/lei-5540-28-novembro-1968-359201-publicacaooriginal-1-pl.html>. Acesso em: 16 nov. 2017.

COUCEIRO, Maria do Loureto Paiva. O porquê e para que do uso das histórias de vida. In: MALPIQUE, Manuela. Histórias de vida. Porto: Campo das Letras, 2002. p. $155-160$.

DOMINICÉ, Pierre. O processo de formação e alguns dos seus componentes relacionais. In: NÓVOA, António; FINGER, Mathias. (Orgs.). 0 método (auto) biográfico e a formação. Natal: EDUFRN; São Paulo: Paulus, 2010. p. 83-95.

FERRAROTI, Franco. Sobre a autonomia do método biográfico. In: NÓVOA, António; FINGER, Mathias. (Orgs.). 0 método (auto)biográfico e a formação. Natal: EDUFRN; São Paulo: Paulus, 2010. p. 31-57.

FONTOURA, Maria Madalena. Fico ou vou-me embora? In: NÓVOA, António. (Org.). Vidas de professores. Porto: Porto, 1992. p. 171-197.

GAGNEBIN, Jeanne Marie. História e narração em Walter Benjamin. São Paulo: Perspectiva, 2013. (Estudos, 142; Dirigida por J. Guinsburg).
Prefácio. In: BENJAMIN, Walter. Magia e técnica, arte e política: ensaios sobre literatura e história da cultura. Tradução de Sérgio Paulo Rouanet; prefácio de Jeanne Marie Gagnebin. 8. ed. revista. São Paulo: Brasiliense, 2012. p. 7-19. (Obras Escolhidas, 1).

GARCÍA, Carlos Marcelo. A formação de professores: novas perspectivas baseadas na investigação sobre o pensamento do professor. In: NÓVOA, António. (Coord.). Os professores e a sua formação. Lisboa: Nova Enciclopédia/39, 1992. p. 51-76.

GÓMEZ, Angel Pérez. O pensamento prático do professor - A formação do professor como profissional reflexivo. In: NÓvOA, António. (Coord.). Os professores e a sua formação. Lisboa: Nova Enciclopédia/39, 1992. p. 93-114.

GOODSON, Ivor. Dar voz ao professor: as histórias de vida dos professores e o seu desenvolvimento profissional. In: NÓVOA, António. (Org.). Vidas de professores. Porto: Porto, 1992. p. 63-78.

HENRIQUES, Eda Maria de Oliveira. Caminhos de conhecimento e formação do professor: um processo de significação. Niterói, RJ: EDUFF, 2005.

JACKSON, Philip W. Enseñanzas implícitas. Buenos Aires: Amorrortu Editores, 1999.

JOSSO, Marie-Christine. Da formação do sujeito... Ao sujeito da formação. In: NÓVOA, António; FINGER, Mathias. (Orgs.). 0 método (auto)biográfico e a formação. Natal: EDUFRN; São Paulo: Paulus, 2010. p. 59-79.

KONDER, Leandro. Walter Benjamin: o marxismo da melancolia. Rio de Janeiro: Campus, 1988.

LEIBNIZ, Gottfried Wilhelm. Principios da filosofia ou a monadologia. Tradução de Fernando Barreto Gallas. On-line: http://www.leibnizbrasil.pro.br, 2007. Disponível em: <http:/ / www.leibnizbrasil.pro. br/leibniz-pdf/monadologia.pdf>. Acesso em: 15 mar. 2017.

NARDI, Roberto; CORTELA, Beatriz S. C. Formação inicial de professores de Física: novas diretrizes, antigas contradições. In: NARDI, Roberto; CORTELA, Beatriz S. C. (Orgs.). Formação inicial de professores 
de física em universidades públicas: estudos realizados a partir de recentes reestruturações curriculares. São Paulo: Editora Livraria da Física, 2015. p. 7-45.

NÓVOA, António. (Org.). Vidas de professores. 2. ed. Porto: Porto Editora, 1992.

. Os professores na virada do milênio: do excesso dos discursos à pobreza das práticas. Educação e Pesquisa [on-line], v. 25, n. 1, p. 11-20, 1999. Disponivel em: <http://www.scielo.br/pdf/ep/ v25n1/v25n1a02.pdf>. Acesso em: 16 mai. 2017.

Professores: imagens do futuro presente. Lisboa: EDUCA, 2009.

A formação tem que passar por aqui: as histórias de vida no projeto Prosalus. In: NÓVOA, António; FINGER, Mathias. (Orgs.). 0 método (auto) biográfico e a formação. Natal: EDUFRN; São Paulo: Paulus, 2010. p. 155-187.

Professores: imagens do futuro presente.

Lisboa: EDUCA, 2011.
NÓVOA, António; FINGER, Mathias. Introdução. In: NÓVOA, António; FINGER, Mathias. (Orgs.). 0 método (auto)biográfico e a formação. Natal: EDUFRN; São Paulo: Paulus, 2010. p. 19-29.

ROSA, Maria Inês Petrucci; RAMOS, Tacita Ansanello; CORRÊA, Bianca Rodrigues; JUNIOR, Admir Soares de Almeida. Narrativas e mônadas: potencialidades para uma outra compreensão de currículo. Currículo sem Fronteiras, v. 11, n. 1, p. 198-217, 2011.

ROSA, Maria Inês Petrucci; RAMOS, Tacita Ansanello. Identidades docentes no Ensino Médio: investigando narrativas a partir de práticas curriculares disciplinares. Pro-Posições, v. 26, n. 1 (76), p. 141-160, 2015.

VIANNA, Deise M.; COSTA, Isa; ALMEIDA, Lucia Cruz de. Licenciatura em Física: problemas e diretrizes para uma mudança. Revista de Ensino de Física, v. 10, p. 144-152, 1988.

Recebido em: 15/01/2019

Aprovado em: 18/04/2019

Heriédna Cardoso Guimarães é doutoranda do Programa de Pós-Graduação em Educação da Universidade Federal Fluminense. Participa do Grupo de Estudos e Pesquisa de Processos Institucionais de Formação (GEPPROFI). e-mail: heriedna@gmail.com

Rua Manoel de Andrade, 191, apt. 102, Centro, São Mateus, ES. CEP: 29930-045

Telefone: (21) 99862-9242

Eda Maria de Oliveira Henriques é Doutora em Educação pela Universidade Federal Fluminense. Pós-doutora em Educação pela Universidade de Aveiro, Portugal. Professora do Programa da Pós-Graduação em Educação da Universidade Federal Fluminense. Coordenadora do Grupo de Estudos e Pesquisa de Processos Institucionais de Formação (GEPPROFI).e-mail: edahenriques@gmail.com

Rua Prof. Marcos Valdemar de Freitas Reis, s/n, Bloco D, Campus do Gragoatá, Centro, Niterói, RJ. CEP: $24210-201$. Telefones: (21) 999295883 / 25499464 